\title{
HEGEMONI ELIT DALAM RITUS AGAMA LOKAL: Studi Keberagamaan Masyarakat Bugis Bone Sulawesi Selatan
}

\author{
Muhammad Rais \\ STAIN Sorong Papua Barat Jalan Basuki Rahmat No.40 Sorong Papua Barat
}

Abstract

Local religious beliefs termed as animism and dynamism by Giddens are still found in the religious practices of Indonesian communities. One of such practices occured in Bugis Ujung-Bone society, South Sulawesi. People's faith in supernatural beings which are mythically believed as giving something meaningful for them is reflected by performing certain rituals in their daily lives. This ritual is performed at home and in a special place called Addewatang. This local belief system was firstly conceived and conceptualized by Sanro Maggangka. It grew into a local ritual tradition in Ujung-Bone society. This local ritual tradition were then acculturated with some formal religion's activities. In the meantime, the figure of sanro becomes very important as a mediator in every religious ritual practiced by the society. Finally, hegemonic domination by the sanro can be observed in every thoughts and actions of the society, especially in their religious practices. In this research, the phenomenon were analyzed with the phenomenological-constructionist analysis. There are two findings of this research. First, there is a public perception that the practice of religious ritual done so far is believed as a part of their formal religion's belief system. Second, there is a strong 
hegemony and dominance of the sanro's role in conceptualizing this local ritual practice into their formal religion's activities. The impact of this mythical belief of the role of sanro and "Putta Sereng" can be seen in the faithfulness of the people to act based on sanro's instructions, the decrease of the people's faith in their own formal religion, and the occurrence of theological confusions in the younger generations of Ujung-Bone society.

Key words: sanro, local religious belief, hegemony, ujung-bone society

\section{Pendahuluan}

Kepercayaan terhadap tradisi leluhur masih banyak ditemukan dan dipraktikkan oleh masyarakat diberbagai wilayah Indonesia. Dalam masyarakat Bugis di Sulawesi Selatan, misalnya, praktik-praktik seperti ini masih dijumpai. Apresiasi masyarakat terhadap mitologi leluhur dan kepercayaan kepada makhluk gaib atau binatang yang memiliki kekuatan supranatural masih dipelihara, meskipun di beberapa tempat terutama pada masyarakat perkotaan, kepercayaan seperti itu sudah hilang. Kepercayaan seperti ini, oleh Anthony Giddens disebut sebagai kepercayaan agama lokal dimana animisme dan totemisme merupakan karakteristik agama lokal (selanjutnya disebut ritus lokal) (Giddens, 1997: 437). Kepercayaan terhadap binatang dengan kekuatan supranatural, serta keyakinan pada mitologi leluhur merupakan perilaku ritus lokal yang dipraktikkan oleh sebuah komunitas di Desa Ujung-Bone, Sulawesi Selatan (Durkheim, 2005: 157). Perilaku mereka didasari atas kepercayaan terhadap eksistensi Putta Sereng sebagai dewa penyelamat.

Menurut sejarahnya, konon makhluk ini membantu masyarakat Ujung ketika mereka dalam keadaan kritis. Sebagai bentuk apresiasinya, digelarlah upacara ritual untuk menghormati makhluk tersebut. Pada perkembangannya hingga sekarang masyarakat Ujung masih meyakini bahwa makhluk itu akan selalu hadir membantunya. Karenanya, untuk menghadirkan dan mengharapkan bantuan dari Putta Sereng, maka konsekuensinya upacara ritual harus selalu diadakan. Pada konteks berbeda juga dapat ditemukan di tempat lain, dimana orang Bugis yang masih memegang tradisi lama percaya akan adanya kemarahan para dewata dan leluhur kepada orang yang melakukan kemungkaran. Untuk menghindari kemungkaran digelarlah 
upacara untuk memohon dan menyembah para dewata (Lathief, 2004: 17). Kondisi seperti ini yang berlangsung dari generasi ke generasi pada masyarakat Ujung.

Ketika ajaran Islam berkembang, tradisi ritual ini tidak hilang, bahkan mengalami akulturasi dengan ajaran agama. Sehingga perilaku keagamaan tampak diwarnai dengan praktik agama lokal, bahkan oleh mereka dipahami bahwa praktik-praktik ritus tersebut dianggap sebagai keharusan dan bagian dari perilaku keagamaan. Salah satu aktor yang paling berpengaruh dalam praktik ritus lokal ini adalah seorang sanro atau dukun. Posisinya sangat strategis sebagai orang yang memberikan pelayanan kepada masyarakat yang mempercayainya berhubungan dengan hal supranatural (Yauri, 2008: 329). Masyarakat Ujung percaya bahwa sanro dapat melakukan komunikasi langsung dengan makhluk metafisik, terutama ketika ritual sedang dilangsungkan. Hal ini secara tidak langsung melegitimasi sanro sebagai aktor penting dalam prosesi upacara ritual. Relasi kuasa tampak pada diri seorang sanro karena otoritasnya sebagai mediator masyarakat dengan makhluk metafisik. Hal ini berimplikasi kuat bagi lahirnya hegemoni-dominasi sanro (aktor) dalam mengkonstruksikan praktik dan eksistensi mitologi tersebut. Apa yang dikatakan Gramsci menjadi jelas dalam praktik ini, di mana hegemoni dan dominasi seseorang terhadap orang lain terjadi, bukan hanya dalam praktikpraktik relasi kekuasaan, tapi juga dalam aktualisasi pemikiran (Gramsci, 1973: 68). Dan hal itu bisa dilihat sebagai strategi untuk mempertahankan kekuasaan (Simon, 1991: 23).

Selain itu, secara faktual sanro selalu mendikotomikan antara praktik ritual dan ajaran agama. Pada acara selamatan, misalnya ketika sesajen berupa makanan telah disiapkan dan seorang tokoh agama atau Imam Desa telah diberikan kesempatan membacakan doa-doa dan barzanji, maka proses selanjutnya diambil alih oleh sanro sambil melakukan tahapan-tahapan akhir ritual dalam upacara tersebut. Karenanya, dikotomi superioritas dan inferioritas serta ekslusivitas maupun inklusivitas juga ditemukan dalam perilaku keagamaan masyarakat ini (Foucault, 1976: 87). Selain di rumah, praktik ritus lokal ini juga dilakukan di sebuah tempat, yang oleh masyarakat Ujung dijuluki "Addewatang”. Tempat ini merupakan bangunan permanen yang di dalamnya terdapat batu-batuan besar dan berserakan, serta dipercayai sebagai lokasi menghilangnya makhluk Putta Sereng yang dimitoskan itu. Masyarakat Ujung melakukan ritual di tempat ini sebagai 
proses akhir upacara yang telah dilakukan di rumah. Begitu kuatnya daya magis tempat (Addewatang) ini, sehingga masyarakat baik yang ada di Ujung, maupun di perantauan rela datang ke Ujung hanya untuk memenuhi janji yang pernah diikrarkan, yaitu melakukan upacara ritual di Addewatang kalau keinginannya berhasil.

Kajian ini menjadi penting mengingat praktik keagamaan masyarakat Ujung banyak diwarnai hal-hal mistik dan tanpa sadar oleh sebagian masyarakat Ujung dianggap sebagai bagian dari tradisi agama (sinkretis). Lebih menarik lagi, karena masyarakat Ujung yang semuanya muslim, lebih memberikan ruang dan kesempatan yang banyak kepada sanro untuk sebuah acara ritus dan keagamaan daripada tokoh-tokoh agama sendiri. Ada kesan bahwa sanro lebih dipercaya dan mumpuni dalam mediasinya untuk mewujudkan segala keinginan yang punya acara atau hajatan. Di sinilah hegemoni sanro masuk dan diterima oleh masyarakat sebagai sesuatu yang wajar (www.wikipedia. org/Hegemony), sehingga ideologi personal atau kelompok dominan sanro dapat menyebar dan dipraktikkan (Strinati, 1995: 165).

Berdasarkan fakta akulturasi ritus lokal dan praktik hegemoni sanro dalam keberagamaan masyarakat Ujung-Bone tersebut, terdapat satu masalah pokok yang menarik untuk dikaji dalam tulisan ini, yakni mengapa praktik ritus lokal dan keberagamaan masyarakat Ujung-Bone dipengaruhi oleh hegemoni sanro? Untuk menjawab permasalahan tersebut, tulisan ini akan menitikberatkan pembahasan pada tiga persoalan utama. Pertama, bagaimana praktik hegemoni sanro terjadi dalam agama dan ritus lokal masyarakat Ujung-Bone. Kedua, tulisan ini juga akan memetakan faktor-faktor apa saja yang melatar belakangi terjadinya hegemoni sanro dalam akulturasi ritus lokal tersebut. Fokus yang ketiga dari tulisan ini adalah pada analisis bagaimana dampak yang ditimbulkan akibat akulturasi ritus lokal tersebut dalam praktik hegemoni sanro. Sebelum ketiga fokus tersebut diuraikan satu persatu. Pada bagian berikut, akan diuraikan setting masyarakat Ujung dalam berbagai aspek kehidupan. Bagian setting tersebut akan menjadi dasar pemahaman tentang bagaimana dominasi dan hegemoni sanro dalam praktik keberagamaan yang mengalami akulturasi ritus lokal tersebut berlangsung dalam masyarakat Ujung-Bone, Sulawesi Selatan.

\section{Ujung: Sebuah Potret Masyarakat Bugis}

Ujung adalah salah satu dari 23 desa yang terdapat di Kecamatan 
Dua Boccoe, Kabupaten Bone Sulawesi Selatan. Posisinya berada di bagian Utara dari Ibukota Watampone dengan jarak tempuh $33 \mathrm{~km}$. Kemudian ke arah Barat menuju Ibukota Makassar sepanjang $210 \mathrm{~km}$. Luas wilayah Desa Ujung tidak kurang dari $20 \mathrm{~km}$ persegi dengan kepadatan penduduk berjumlah $50 \mathrm{orang} / \mathrm{km}$. Jalur transportasi ke wilayah ini relatif sulit akibat sarana jalan yang rusak. Meskipun terdapat jalan alternatif yang bisa diakses dengan cepat, namun tidak difungsikan dengan baik karena seringnya terkena banjir. Sebelum dilakukan pemekaran wilayah oleh pemerintah kota, teritori Desa Ujung disatukan oleh beberapa desa kecil, di antaranya Desa Ujung Pero, Ujung Rilau, dan Desa Matajang. Pada tahun 1993, oleh pemerintah pusat dikeluarkan keputusan mengenai pemekaran beberapa wilayah daerah, termasuk Desa Ujung yang merupakan bagian dari wilayah Kabupaten Bone. Menurut data sensus penduduk tahun 2007 jumlah penduduk Desa Ujung sebanyak 1.044 jiwa, dengan klasifikasi wanita sebanyak 640 jiwa dan laki-laki sebanyak 404 jiwa. Status kependudukan di Desa Ujung diklasifikasi menjadi tiga, yaitu; pertama, penduduk menetap, penduduk yang telah menetap selama bertahun-tahun dari generasi ke generasi tinggal di Desa Ujung. Kedua, penduduk tidak menetap, yaitu warga Ujung yang mempunyai tempat tinggal dan keluarga di Ujung, tapi waktunya lebih banyak dihabiskan di luar daerah karena ikatan pekerjaannya. Ketiga, penduduk pendatang, yaitu orang yang datang dari daerah luar Ujung dan tinggal menetap di Desa Ujung (Rais, 2008: 138-139).

Untuk mengetahui potensi ekonomi masyarakat Ujung, maka dapat dilihat dalam dua tipologi masyarakatnya, yaitu masyarakat Ujung lokal dan masyarakat Ujung regional. Masyarakat yang pertama (lokal) adalah penduduk menetap yang tinggal dan bekerja di Desa Ujung. Mayoritas kehidupan ekonomi mereka berada pada tingkat menengah ke bawah. Produktivitas mereka selain berdagang kecil-kecilan, juga pekerjaan yang dilakukan bermacam-macam, di antaranya ada yang menjadi buruh lepas, baik di toko-toko, bangunan, pasar, maupun pekerjaan yang dilakukan di rumah, di sawah dan di kebun. Hal yang menarik dari masyarakat Ujung lokal adalah semua penduduknya beraktivitas, baik wanita, orang tua, anak-anak, apalagi para laki-laki, mereka mempunyai etos kerja yang tinggi dalam mencari uang. Kondisi ini pulalah yang berimplikasi kurangnnya minat anak-anak mereka dalam pendidikan akibat keterikatan dan keasyikan dalam pekerjaan. Kedua, masyarakat Ujung regional, yaitu penduduk Ujung 
yang tidak menetap di Ujung dan berdomisili di beberapa wilayah di luar Ujung. Ada dua karakteristik tidak menetap dalam masyarakat ini, pertama mereka mempunyai keluarga yang berdomisili di Ujung, tapi kepala rumah tangganya sendiri tinggal dan bekerja di luar. Biasanya mereka pulang hanya sekali dalam tiga bulan. Kedua masyarakat yang mempunyai tempat tinggal di Ujung, tapi mereka tinggalkan sementara dan berdomisili, serta bekerja di luar daerah sambil membawa keluarganya. Kondisi ekonomi masyarakat ini maju dan mayoritas mereka kaya. Pekerjaan yang mereka lakoni umumnya berdagang, sehingga keberhasilan mereka dalam berdagang menambah pencitraan diri orang-orang Ujung sebagai pedagang ulung.

Menurut sejarahnya, Desa Ujung menyimpan berbagai macam cerita mistis dan beberapa peristiwa sejarah masa lalu. Salah seorang penasehat Raja Bone ke-32, Haji Andi Mappanyukki berasal dari Desa Ujung (Rais, 2001: 82). Beliau adalah seorang bissu. Terdapat berbagai pendapat me-ngenai istilah bissu di antaranya bissu dianggap berasal dari kata bessi, dalam bahasa Bugis berarti bersih (Lathief, 2004: 2). Dianggap bersih karena mereka tidak mengalami haid dan suci. Peran seorang bissu selain sebagai pendeta, dukun dan ahli ritual, juga sebagai penghubung antara manusia dengan dewata, karena untuk berkomunikasi dengan dewata harus menggunakan bahasa torilangi atau bahasa langit (bahasa Bugis kuno) (Yauri, 2008: 325). Berawal dari struktur bissu inilah dikonstruksi konsep tentang sanro (dukun) di Ujung dan bissu ini pula adalah orang yang pertama melegitimasikan dirinya sebagai sanro sehingga dikenal (Latif, 2004: 2). Sanro tersebut adalah sanro Maggangka. Di Ujung, sanro/bissu ini membuat struktur sosial dalam masyarakat Ujung dengan mendirikan lembaga-lembaga adat. Kini, lembaga adat tersebut tidak berfungsi lagi dan digantikan dengan struktur sanro yang eksis hingga sekarang. Selain itu, terdapat dua institusi besar dalam struktur masyarakat Ujung. Pertama, lembaga pendidikan keagamaan di Ujung yaitu pesantren al-Ikhlas Ujung. Kehadiran pesantren ini merupakan respons tokoh masyarakat Ujung yang prihatin terhadap perkembangan pendidikan di Desa Ujung. Kedua, adanya komunitas Tarekat Khalwatiyah. Menurut khalifah (pemimpin) tarekat ini, hampir lima puluh persen masyarakat Ujung bergabung dalam tarekat ini, termasuk di antara mereka adalah sanro.

Desa Ujung termasuk desa yang masih memelihara kepercayaan leluhur dan mempertahankan tradisi masyarakat setempat. Kepercayaan dan tradisi adat-istiadat dalam masyarakat sering menyatu dalam sebuah 
acara massal yang dilakukan oleh masyarakat Ujung setiap tahunnya. Bagi masyarakat Ujung acara seperti itu dianggap sebagai bentuk syukur atas keberhasilan hasil panen yang telah diperolehnya. Meskipun masyarakat Ujung semuanya muslim, namun kepercayaan terhadap makhluk metafisik masih tinggi. Kepercayaan itu berawal dari adanya cerita seorang sanro yang mengisahkan betapa orang-orang Ujung hampir musnah dimangsa oleh sosok binatang yang bernama "sereng". Dan di saat yang sama makhluk yang kemudian disebut "Pa-Putta", datang membantu orang-orang Ujung hingga dapat diselamatkan dari binatang tersebut. Putta dimaknai sebagai penghabis/penghancur, sedang sereng diartikan sebagai nama burung pemangsa. Jadi, Putta Sereng adalah penghancur burung pemangsa. Sosok "Pa-Putta" inilah yang diyakini masyarakat Ujung sebagai makhluk gaib yang senantiasa akan datang membantu orang-orang Ujung dalam kesusahan di manapun mereka berada. Sosok gaib ini pula dipercaya oleh masyarakat Ujung menghilang di sebuah batu besar yang terdapat di Addeawatang. Implikasinya kepercayaan ini melahirkan tradisi dalam masyarakat Ujung, yaitu tradisi ritual atau upacara, baik yang dilakukan di rumah maupun di Addewatang. Salah satu harapan yang diinginkan oleh mereka adalah diwujudkannya segala apa yang diinginkan.

Karakteristik masyarakat Ujung adalah pekerja, hampir kehidupan sehari-harinya lebih banyak dihabiskan dalam pekerjaan. Pekerjaan sekecil apapun dilakoninya sepanjang hal itu bisa mendatangkan uang. Prinsip inilah yang membuat sebagian masyarakat Ujung meninggalkan kampung halamannya demi mencari penghasilan yang lebih besar. Implikasinya, terjadi ekspansi pasar di mana orang berorientasi kepada pencarian "kehidupan yang lebih baik" dalam berbagai bentuk dan tingkat, yang diistilahkan Irwan Abdullah sebagai etos kerja kapitalistik (Abdullah, 2006: 112). Kecenderungan ini pulalah yang membuat masyarakat Ujung mencari jalan pintas agar secepat mungkin bisa mendapatkan apa yang diinginkannya, misalnya mendatangi tempat-tempat keramat yang dianggap bisa memberikan petunjuk dan kemudahan dalam pekerjaannya. Perilaku mendatangi Addewatang sebagai tempat keramat dan melakukan ritual di dalamnya adalah pemandangan sehari-hari yang dapat ditemukan dalam kehidupan masyarakat Ujung. Acara dan praktik-praktik keagamaan yang sinkretis juga mudah ditemukan di tempat ini. 


\section{Hegemoni Sanro dalam Praktik Keberagamaan dan Ritus Lokal}

Hegemoni sanro dalam aktivitas keberagamaan masyarakat Ujung dapat dilihat pada acara-acara selamatan (tasyakuran), seperti upacara perkawinan, keberhasilan panen raya, kelahiran bayi, merantau ke daerah lain, ketika membeli barang-barang baru, dan termasuk kalau naik rumah baru. Konsepsi yang dikonstruksi sanro membuat orang-orang Ujung meyakini bahwa kesempurnaan acara-acara selamatan tersebut baru dianggap sah ketika dilakukan selamatan di Addewatang. Konsepsi ini oleh sebagian ahli dinilai sebagai gabungan yang bersifat kultural-religius (Soedarsono, 1986: 39). Meskipun prosesnya rumit, panjang dan relatif butuh biaya, tapi hal itu tetap dilakukan oleh masyarakat setempat. Pada acara perkawinan misalnya, sebelum calon pengantin dinikahkan salah satu dari mereka terlebih dahulu harus datang ke Addewatang untuk mengharapkan restu dari leluhur. Demikian pula ketika usai perkawinan diadakan, keduanya diharuskan datang kembali dan melakukan ritual di dalamnya. Pola-pola yang dilakukan semuanya sama pada acara selamatan, baik pada acara kelahiran bayi, perkawinan, merantau keluar daerah, maupun ketika membeli barang-barang baru. Yang sedikit berbeda pada ritual membeli barang baru, ketika barang seperti mobil yang dibeli kebiasaan masyarakat Ujung membawa mobil baru itu ke Addewatang sambil makan sesajian yang dibawa ke dalam mobil tersebut.

Praktik dominasi-hegemoni sanro juga terlihat ketika digelar sebuah upacara selamatan atau keberhasilan panen raya masyarakat Ujung. Kegiatan ini rutin setiap tahun diadakan oleh masyarakat setempat, terutama setelah keberhasilan usaha para petani dalam panen. Bentuk dan prosesi acara ini semua dikonstruksi oleh sanro, seperti mengadakan ritus dan acara-acara kesenian dan budaya. Dari sekian banyak acara selamatan yang sering dilakukan masyarakat Ujung, hanya pada kegiatan ini melibatkan orang luar yang banyak, bahkan mereka memang sengaja diundang untuk menghadiri acara tersebut, mulai dari unsur pemerintah, tokoh masyarakat dan khalayak umum dengan maksud bersama-sama menikmati hasil panen yang telah diperoleh masyarakat Ujung. Dihadirkannya tiga ekor sapi atau kerbau yang dipotong dalam prosesi acara ini adalah bagian yang dikonsepsikan sanro. Masyarakat secara kolektif merespons permintaan sanro tersebut dan memenuhi segala apa yang menjadi faktor penting untuk acara ini, misalnya tiga ekor sapi dipotong di tiga lokasi; di Addewatang, di tempat pusat acara 
kesenian-budaya digelar, dan di lokasi pertanian. Daging ketiga ekor sapi tersebut kemudian dibagikan ke masyarakat dan dijadikan salah satu menu makanan yang harus disiapkan masyarakat Ujung untuk menyambut dan menjamu tamu-tamu yang datang dari luar.

Pada acara-acara keagamaan, seperti naik haji, peringatan Isra Mi'raj dan Maulid Nabi Besar Muhammad SAW juga tidak luput dari dominasi yang dikonsepsikan oleh sanro. Bagi masyarakat Ujung, sebelum berangkat ke tanah suci terlebih dahulu datang dan melakukan ritual ke Addewatang. Agama bagi komunitas Ujung bukan lagi merupakan sumber nilai dalam pembentukan kehidupan religius, tetapi lebih sebagai instrumen gaya hidup. Ini menunjukkan suatu ekspresi lebih terikat pada proses konsumsi dalam rangka "identifikasi diri", yang disebut Friedman sebagai bentuk cultural strategy of self definition (Abdullah, 2006: 193). Dalam konteks ini proses estetisasi kehidupan terjadi, produk yang dikonsumsi tidak dilihat dari fungsi, tetapi dari simbol yang berkaitan dengan identitas dan status (Abdullah, 1994: 22). Karenanya, ketika mereka telah menunaikan ibadah haji mereka kembali lagi ke Addewatang paling tidak menunjukkan diri bahwa mereka pulang dalam keadaan selamat. Haji dalam hal ini tidak lagi dipahami sebagai sebuah perjalanan spiritual (sakral), tetapi telah menjadi "produk" yang dikonsumsi dalam rangka identifikasi diri tersebut. Ikatan emosional seperti inilah yang banyak diyakini masyarakat Ujung sehingga dari sekian orang yang pernah datang ke Addewatang merasa segala keinginannya dapat diwujudkan dalam waktu yang tidak lama. Keterikatan masyarakat Ujung terhadap ritual di Addewatang ditunjukkan pula pada peringatan Isra Mi'raj dan Kelahiran Nabi Muhammad SAW. Meskipun acara seremonial tetap dilakukan di masjid sebagaimana biasanya, namun mayoritas masyarakat melangsungkannya juga di Addewatang.

Untuk perayaan hari-hari raya besar Islam, seperti Idul Fitri dan Idul Adha juga ditemukan betapa ritual di Addewatang ini menjadi sesuatu yang penting dalam kognisi dan kehidupan masyarakat Ujung. Pada kedua perayaan inilah terjadi mobilisasi besar-besaran dari masyarakat Ujung untuk sengaja datang ke Ujung melakukan ziarah ke Addewatang. Bahkan, mayoritas mereka memang mengagendakan kedatangannya ke tempat tersebut ketika pada perayaan kedua hari raya ini tiba, terutama masya-rakat Ujung yang berdomisili di luar Desa Ujung. Pola kedatangan mereka bervariasi, ada yang datang setelah shalat 'Id ditunaikan dan sebagian juga datang setelah 
dua atau tiga hari setelah lebaran. Khusus perayaan hari raya kurban (Idul Adha), menarik diperhatikan perilaku sebagian masyarakat Ujung, begitu kuat dan dominannya sanro dalam mengaktualisasikan pemikirannya dalam ritual, sehingga sapi atau kambing yang akan dikorbankan diinstruksikan dibawa dan dikorbankan di Addewatang. Perilaku masyarakat ini terkesan bahwa binatang yang dikorbankan dapat juga dimaknai sebagai tumbal kepada makhluk metafisik.

Adapun bentuk-bentuk hegemoni yang dikonsepsikan sanro dalam ritus lokal dan praktik keberagamaan masyarakat Ujung dapat diklasifikasi dalam tiga hal. Pertama, pada proses upacara ritual. Kedua, pada kognisi dan praktik keagamaan. Pada bagian pertama, bentuk hegemoni dalam proses upacara ritual dapat dilihat pada penentuan kuantitas makanan. Masyarakat mengklasifikasi porsi makanan yang dihidangkan antara yang disajikan di rumah dan di Addewatang. Biasanya, makanan yang disiapkan di rumah terlebih dahulu dipisahkan, karena makanan yang akan dibaca dan dibaraanjikan oleh tokoh agama atau imam desa berbeda dengan makanan yang akan dibaca dan dimantrai oleh sanro. Selain itu, makanan untuk upacara ritual jauh lebih banyak porsinya dibanding yang disajikan dan dimakan di rumah, padahal orang-orang yang makan di rumah lebih banyak biasanya mereka yang hadir beberapa tokoh masyarakat, agama, dan unsur pemerintah yang sengaja diundang daripada orang yang nantinya makan di Addewatang. Dalam praktik ritual di rumah inilah hegemoni sanro sangat tampak, terutama perannya dalam pembacaan doa-doa. Pada konteks ini pula, personifikasi peran sanro lebih dominan daripada tokoh agama atau imam desa.

Bentuk hegemoni lain, kedua juga dapat dilihat ketika sanro mengonsepsikan pemikiran masyarakat Ujung dalam ketergantungannya terhadap sosok Putta Sereng. Meskipun masyarakat Ujung masih mengaku mentauhidkan Tuhan dalam beragama, tapi perilaku dan ketergantungannya pada sosok ini masih tetap dilakoninya. Persoalan-persoalan duniawi, seperti kesejahteraan dan kehidupan keluarga, ekonomi, dan lain sebagainya masih disandarkan pada mitos leluhur mereka. Karenanya, ketika salah seorang anggota keluarga mereka mengalami kesurupan atau sakit, maka asosiasinya mengarah pada sosok makhluk gaib ini. Mereka memaknai sosok Putta Sereng berada dalam jasad tersebut. Indikator ini kemudian berimplikasi dilakukannya ritual sebagai respons masyarakat 
terhadap Putta Sereng, sekaligus menunjukkan bahwa mereka masih tetap loyal. Di bidang kehidupan ekonomi misalnya, telah menjadi tradisi bagi masyarakat Ujung ketika ingin memulai usaha, maka yang harus mereka lakukan pertama adalah mendatangi Addewatang. Di tempat itu dilakukan upacara ritual, memohon dan berikrar kalau usahanya berhasil, maka akan datang kembali menziarahi Addewatang.

Bagian ketiga, hegemoni sanro dapat dilihat pada praktik dan kognisi keagamaan masyarakat. Dalam struktur sosial masyarakat Ujung, selain komunitas ritus lokal ini, juga terdapat komunitas tarekat (thariqah) khalwatiyah yang relatif lama eksis di Desa Ujung. Menurut khalifahnya (pemimpinnya), sebagian besar masyarakat Ujung adalah pengikut tarekat ini. Ketika disinggung mengenai sanro; apakah dia termasuk bagian yang diklaim sang khalifah, secara tegas dijawab "bukan", karena secara prinsipil praktik yang dilakukan sanro tidak disetujui oleh khalifah dan secara akidah bertentangan dengan ajaran tarekat ini. Ungkapan yang paradoks ketika sanro dalam pengakuannya mengklaim kalau dirinya adalah bagian (jama'ah) dari tarekat ini. Bahkan, diakui sering diajak bersama dalam berdzikir yang merupakan media spiritual dari tarekat ini oleh sang khalifah. Bahkan ditambahakan sanro, bahwa hampir sebagian besar masyarakat Ujung penganut ritus lokal, juga adalah jamaah tarekat khalwatiyah. Dalam konteks ini ada dua hal yang dapat dilihat betapa kuatnya hegemoni sanro dalam praktik dan kognisi masyarakat Ujung; pertama, sanro berhasil menghegemoni khalifah untuk tidak terbuka atau tidak jujur dalam mengakui realitas ini. Kedua, sanro secara tidak langsung mendekonstruksi kognisitas ajaran tarekat yang telah dipraktikkan masyarakat Ujung ke dalam sikap ambivalensi dengan tetap mengapresiasi ritus lokal.

Pada perkembangannya, efektivitas hegemoni pemikiran sanro dalam agama dan ritus lokal direspons beragam oleh masyarakat Ujung. Meskipun mayoritas masyarakat Ujung adalah penganut ritus lokal ini, bukan berarti tidak ada di antara mereka yang menolak atau tidak setuju terhadap apa yang dipraktikkan oleh masyarakat selama ini. Masyarakat Ujung yang berani menolak perilaku tersebut, berasal dari mereka yang memiliki latar belakang pendidikan agama. Tokoh-tokoh agama, imam desa, dan sebagian tokoh masyarakat tertentu adalah mereka yang pernah menempuh pendidikan agama. Sikap mereka jelas bahwa apa yang dipraktikkan masyarakat Ujung selama ini tidak benar. Karenanya, ketika mereka menjadi partisipan dalam 
sebuah acara selamatan yang dilakukan masyarakat, peran mereka hanya sebatas mengawali sebuah pembacaan doa dan sekaligus barzanji setelah itu mereka makan kemudian meninggalkan acara tersebut. Bagi masyarakat Ujung, sikap yang ditampilkan oleh tokoh-tokoh agama dan masyarakat ini dianggap biasa dalam pandangan sehari-hari mereka. Bahkan bukan menjadi sesuatu yang harus diperdebatkan, apalagi untuk dipermasalahkan.

Berbeda dengan mayoritas masyarakat Ujung, terutama bagi mereka penganut ritus lokal. Sikap dan apresiasi mereka terhadap praktik tersebut dianggap sebagai sesuatu yang wajar, bahkan dipahami sebagai bagian dari tradisi keagamaan. Mereka justru mencontohkan bahwa tradisi pembacaan doa dengan menggunakan ayat-ayat suci dan barzanji merupakan praktik syariat agama dari budaya masyarakat tradisional (Rais, 2008: 152). Demikian juga praktik-praktik upacara ritual yang mereka lakukan, menurutnya, makanan yang disajikan dalam setiap upacara ritual terlebih dahulu dibacakan doadoa keselamatan dan kesyukuran, sekaligus diniatkan membaca shalawat kepada junjungan Nabi Muhammad SAW. Jadi, efektivitas penerimaan masyarakat Ujung ini terhadap praktik-praktik ritual terhadap agama, baik yang dilakukan di rumah maupun di Addewatang tetap dipahami sebagai penghubung (washilah) kepada Tuhan.

Selain kedua sikap di atas, efektivitas itu dapat dilihat dari sikap resistensi sebagian kecil dari masyarakat Ujung. Ketika lembaga pendidikan Pesantren al-Ikhlas berdiri di Desa Ujung tahun 2003, terjadi perubahan sikap pada perilaku sebagian anak-anak Ujung yang sempat disekolahkan di pesantren ini. Sebagaimana kebiasaannya, kalau sebuah acara ritual diadakan mereka diperintahkan oleh orang tua mereka membawa sesajian atau makanan ke Addewatang. Namun kemudian, kebiasaan itu tidak dilakukan lagi oleh anak-anak Ujung, bahkan mereka melakukan resistensi terhadap orang tua mereka sendiri ketika diperintahkan untuk membawa sesajian ke Addewatang. Hal ini menunjukkan bahwa resistensi yang di-tampilkan anak-anak Ujung kepada orang tua mereka merupakan sikap bagaimana hegemoni yang dikonstruksikan sanro, baik dalam bentuk kuasa, maupun aktualisasi pemikirannya direspons berbeda oleh sebagian masyarakat Ujung.

\section{Faktor-Faktor Lahirnya Dominasi Sanro}

Kuatnya legitimasi sanro dalam struktur masyarakat Ujung menjadi salah satu faktor pengukuhan kuasa sanro. Seperti dijelaskan sebelumnya 
bahwa sanro atau dukun adalah orang yang memiliki kekuatan mistis dan mampu berkomunikasi dengan sosok makhluk metafisik. Konsepsi yang dikonstruksi sanro, baik melalui ucapan (titah) maupun dalam tindakan dianggap masyarakat sebagai representasi makhluk gaib. Karenanya, sanro ditempatkan pada posisi penting dan strategis, baik di luar prosesi upacara, maupun dalam konteks upacara itu sendiri. Konsekuensinya, sanro mempunyai kesempatan melegitimasi kepentingan individual dalam prosesi ritual keagamaan. Kecenderungan ini oleh Beyer dilihat sebagai "privatisasi agama", di mana sanro menunjukkan proses individualisasi dalam penghayatan dan praktik agama (Beyer, 1991: 23). Fungsi utama sanro adalah memediasi ritual yang dilakukan di rumah dan di Addewatang. Kehadiran sanro menjadi kunci keberhasilan sebuah upacara, sebab tanpa kehadirannya ritus dan upacara-upacara apa saja tidak akan terlaksana.

Menurut sejarahnya terdapat tujuh sanro yang pernah mendampingi masyarakat Ujung dari beberapa generasi dan eksistensi mereka dalam masyarakat masing-masing mempunyai pengikut tersendiri (Rais, 2008: 154). Proses perekrutan sanro ditempuh melalui dua cara. Pertama, sanro yang berasal dari garis keturunan sanro pertama, sanro Maggangka. Kedua, sanro yang proses pengangkatannya diterima lewat mimpi dan dalam mimpi tersebut sanro bertemu dan menerima langsung dari Putta Sereng. Keterlibatan sanro dalam prosesi upacara ritus lokal didorong oleh adanya nilai kolektivitas masyarakat yang menempatkan seorang sanro dalam posisi penting. Bentuk-bentuk kekuatan sanro yang dipercaya oleh masyarakat dapat dilihat pada prosesi upacara ritual berlangsung. Dalam konteks ini sanro akan mengalami kesurupan yang dimaknai masyarakat sebagai menyatunya makhluk gaib Putta Sereng ke dalam jasad seorang sanro. Akhirnya, apa yang keluar dari mulut sanro ketika dalam keadaan tidak sadar merupakan titah yang harus diemban dan dilaksanakan oleh yang punya hajatan. Bagi masyarakat Ujung sulit untuk menguji dan menolak instruksi yang dikomunikasikan sanro dalam proses ritual, sebab kuatnya legitimasi yang dimiliki. Sanro berhasil meyakinkan masyarakat lewat perilaku sakralnya dalam upacara tersebut, tanpa ingin tahu kebenaran yang terdapat di balik sebuah upacara atau ritual.

Sosok sanro memang sulit dipisahkan dalam praktik-praktik ritus lokal, sebab konsep-konsep yang dikonstruksikan dan dipraktikkan masyarakat Ujung tidak terlepas dari perspektif yang dibangun sanro, 
meskipun ditampilkan dalam bentuk metafisik. Karenanya, untuk melihat pola keterlibatan sanro dalam prosesi upacara dapat dilihat dari tiga model motivasi aktor, yaitu individual, ideologi, dan psikologi. Pada aspek individual misalnya, kepentingan personal aktor jelas terbaca, sebab setiap orang yang datang menggunakan jasa sanro biasanya memberikan balas jasa berupa uang dan makanan, apalagi secara sosial ekonomi kehidupan para sanro di Ujung dapat dikatakan pas-pasan karena tidak adanya pekerjaan tetap yang dimiliki sanro. Pada aspek ideologi, perspektif yang dikonstruksi sanro adalah berupaya menjaga dan memelihara keyakinan dan kognisi masyarakat Ujung tentang eksistensi makhluk gaib ini, terutama kaitannya dalam mewujudkan harapan-harapan hidup bagi masyarakat Ujung. Demikian pula, pada aspek psikologi, sanro berhasil mengonstruksi sebuah kepercayaan dalam kognisi masyarakat Ujung hingga mereka benar-benar yakin dan takut terhadap sosok yang disakralkan.

Faktor kedua, kuatnya keyakinan masyarakat Ujung terhadap eksistensi mitos Putta Sereng. Pengetahuan atau persepsi yang diyakini tentang mitos ini ada dua. Pertama, hadirnya sosok Putta Sereng ini setiap saat dalam kehidupan orang-orang Ujung. Keyakinan masyarakat Ujung terhadap mitos Putta Sereng sangat tinggi dan mendalam, begitu dekatnya di hati setiap orang (penganut) sehingga selalu merasa diawasi dan hadir dalam kehidupan masyarakat Ujung di manapun mereka berada, sebagaimana dikatakan oleh salah seorang informan sanro berikut ini: “...Ada orang yang pernah naik kapal, kemudian kapalnya mengalami musibah, semua orang panik, bahkan ketika lampu sudah mati, ada yang bersyahadat. Orang ini menelpon untuk minta tolong. Lalu saya waktu itu diam saja sambil melipat tangan, kata orang itu. Itu saja yang saya ingat, yaitu Putta Sereng yang tibatiba hadir berdiri di hadapnnya, kemudian angin berhenti dan kapal normal kembali. Jadi, lebih jauh dijelaskan bahwa meskipun simbolnya (tuladanya) saja yang dilihat dan teringatlah semua kekuasaan yang diberikan oleh Allah SWT". Masyarakat mengasumsikan bahwa setiap tempat-tempat yang dikeramatkan dan angker, maka dianggap sebagai tempat bersemayangnya sosok Putta Sereng. Karenanya, kehadiran dalam kognisi masyarakat Ujung sosok ini sangat ditakuti.

Kedua, keyakinan itu dipersepsikan masyarakat Ujung sebagai warisan/tradisi leluhur yang diistilahkan Attoriolong. Menurutnya, ritus lokal ini adalah sesuatu yang sudah ada dan turun-temurun ditradisikan 
oleh masyarakat Ujung dari generasi ke generasi. Bahkan, ketika Islam sedang berkembang di Kerajaan Bone ritual ini tetap dilestarikan dan diperta-hankan (Rais, 2008: 154). Meskipun pada perkembangannya ritual ini mengalami perubahan karena dimasukkannya nilai-nilai keagamaan (Islam) dalam bagian prosesi ritual. Menurut Soedjono Tirtokoesoemo ritual seperti ini dianggap sebagai versi upacara yang telah diubah dan disesuaikan dengan tradisi Islam (Abdullah, 2002: 12). Hal senada juga diungkapkan oleh salah seorang khalifah Khalwatiyah, beliau mengatakan: "Ada dua makna yang diyakini masyarakat Ujung dalam melakukan ritual ini. Pertama, sebagai pengikut (Akkacuereng) tradisi leluhur (Attoriolong). Kedua, sebagai bentuk rasa syukur karena habis bernazar kepada Tuhan”. Bagi mayoritas masyarakat Ujung melanggar atau tidak mengikuti tradisi ini merupakan dosa besar, dan penghianatan kepada leluhur. Karenanya, sikap dan perilaku yang diambil sesuai dengan apa yang telah dan pernah dilakukan leluhur mereka, seperti menyiapkan dan melakukan upacara ritual sebagaimana mestinya.

Perilaku yang sama juga dilakukan oleh masyarakat Ujung ketika diyakini sosok Putta Sereng ini hadir pada diri orang sakit yang penyakitnya tidak dapat didiagnosa oleh dokter dan pada orang yang kesurupan, karena dianggap hadirnya sosok makhluk ini ke dalam raganya. Akhirnya, orangorang yang sakit tidak segera dibawa ke dokter, tetapi masyarakat lebih cenderung membawa dulu ke dukun (sanro). Karenanya, semua kejadian ini direspons dan disikapi oleh masyarakat Ujung dengan mengadakan upacara ritus lokal, baik di rumah maupun di Addewatang.

Faktor ketiga adalah keterbatasan masyarakat Ujung terhadap akses pendidikan agama. Kurangnya akses pendidikan agama bagi masyarakat Ujung merupakan faktor mudahnya menerima dan melakukan apa yang dikonsepsikan sanro dalam praktik keberagamaan dan ritus lokal masyarakat Ujung. Hal itu juga menjadi kendala utama dalam membangun interaksi religius dan kognisitas bersama dalam pemahaman keagamaan. Konsepsi dan perilaku mereka terhadap keyakinan ritus lokal masih kuat mewarnai sendisendi kehidupan masyarakat Ujung. Implikasi itu tampak pada kurangnya minat mereka pada pendidikan. Pada tahun 1960-an sebuah lembaga pendidikan agama ditempatkan di desa ini dengan maksud memberikan pencerahan kepada masyarakat, tetapi direspons beragam oleh masyarakat Ujung. Hanya sebagian kecil saja yang menyekolahkan anak-anak mereka 
di madrasah tersebut. Kemudian pada tahun 2003, salah seorang tokoh masyarakat setempat mendirikan sebuah pesantren yang diberi nama alIkhlas juga tidak memberikan dampak yang signifikan bagi masyarakat Ujung dalam menyekolahkan anak-anak mereka di pesantren itu, padahal oleh penyelenggara pendidikan telah memberikan dispensasi sekolah gratis buat anak-anak mereka, tetapi tetap saja kurang diminati.

Terdapat tiga hal yang membuat sikap masyarakat Ujung apatis terhadap pendidikan agama. Pertama, pendidikan memang dianggap tidak terlalu penting dalam kehidupan mereka. Kedua, pengaruh lingkungan dan kultur masyarakat Ujung yang mayoritas pedagang dan pekerja keras. Pendidikan bagi masyarakat Ujung dianggap tidak terlalu penting. Menurutnya, kalau sudah bisa mengenal baca tulis (membaca) dan ilmu hitung, maka tidak perlu lagi sekolah atau melanjutkan pendidikan tinggi, apalagi mayoritas masyarakat Ujung cenderung berorientasi pedagang yang dipersepsikan cukup dengan kedua kecakapan itu mereka bisa survive. Kultur dan lingkungan seperti itulah yang mewarnai aktivitas keseharian masyarakat Ujung, baik yang berdomisili di Desa Ujung, maupun masyarakat Ujung diperantauan. Anehnya, sikap dan pemahaman me-reka tidak berubah meskipun berada dan telah berinteraksi di daerah lain.

Ketiga, khawatir pemahaman agama dapat mempengaruhi sikap dan kognisi mereka tentang perilakunya selama ini. Sikap kekhawatiran masyarakat Ujung terhadap pengaruh pendidikan agama dalam praktik ritus lokal juga ditunjukkan ketika adanya mobilitas masyarakat Ujung yang melakukan resistensi dan penolakan atas rencana pendirian Pesantren al Ikhlas Ujung pada saat itu. Mereka memahami bahwa berdirinya pesantren di Desa Ujung akan mematikan aktivitas dan tradisi masyarakat Ujung yang selama ini diyakininya. Akhirnya, dalam proses negosiasi yang panjang dihasilkan suatu kesepakatan bahwa pesantren tidak akan me-ngusik apa yang selama ini ditradisikan oleh masyarakat Ujung. Setelah kesepakatan itu diterima rencana pembangunan pesantren tetap dilanjutkan. Hal ini menunjukkan betapa kuat daya tarik dan dominasi ritus lokal dalam kognisi masyarakat Ujung, hingga melahirkan sikap antipati terhadap khazanah dan pengetahuan keagamaan itu sendiri.

\section{Dampak Hegemoni Sanro dalam Akulturasi Ritus Lokal}

Tingginya loyalitas masyarakat terhadap sosok sanro menjadi dampak 
yang muncul akibat konsepsi dan hegemoni sanro dalam praktik keberagamaan masyarakat Ujung. Kepatuhan (loyality) itu diwujudkan dalam dua respons. Pertama, sanro dianggap sebagai representasi Putta Sereng. Sebagai representasi mahkluk metafisik, sanro dianggap mampu menyelesaikan segala persoalan yang dialami oleh masyarakat Ujung. Karenanya, dalam kehidupan sosial kultural peran sanro di luar praktik ritus juga dibutuhkan, terutama dalam menyembuhkan masyarakat yang kerasukan makhluk gaib. Masyarakat percaya bahwa segala ucapan yang keluar dari mulut sanro terutama ketika proses ritual diadakan diyakini sebagai titah sosok Putta Sereng. Segala persoalan duniawi dan metafisik biasanya diserahkan kepada sanro. Sanro seolah dapat memberikan solusi pada setiap persoalan dalam kehidupan masyarakat. Karenanya, kepatuhan masyarakat yang tinggi terhadap sanro menempatkan posisi sanro sebagai superioritas dan eksklusivitas (Foucault, 1976: 124). Kedua, sanro lebih ditempatkan pada posisi yang tinggi (superior) dari pada tokoh agama (imam desa). Sikap seperti ini terlihat ketika upacara yang dilaksanakan di rumah. Tradisi masyarakat dalam setiap acara yang dilakukan biasanya selain me-ngundang masyarakat umum, juga mengundang tokoh-tokoh agama dan struktur pemerintah desa. Sebagaimana tradisi acara orang-orang Bugis, masyarakat yang diundang biasanya diminta membaca barzanji, tetapi kalau imam desa hadir, maka yang membacakan biasanya hanya imam desa dan tokoh-tokoh agama setempat.

Dalam konteks masyarakat Ujung, pembacaan doa dan barzanji pada sebuah acara merupakan tahap awal dimulainya sebuah upacara ritual apa saja. Seorang sanro tidak hadir dalam proses awal acara tersebut, sebab posisi dan peran sanro dalam hal ini berbeda. Sanro akan dihadirkan ketika acara tahap awal ini selesai dan dilanjutkan oleh sanro pada tahap kedua. Waktu yang diberikan kepada sanro juga panjang dan lama, sebab banyaknya bagianbagian yang harus dilalui sanro dalam prosesi upacara. Sikap eksklusivitas tampak pada diri sanro yang melakukan prosesi acara secara sistematis. Inilah yang menjadi bentuk sikap diskriminatif masyarakat terhadap posisi imam desa dan tokoh-tokoh agama dalam struktur masyarakat Ujung. Tingginya kepatuhan masyarakat Ujung terhadap sanro juga dapat dilihat dari motivasi masyarakat terhadap sanro. Selama ini, masyarakat Ujung merasa terbantu dengan mediasi yang dilakukan sanro dalam setiap upacara ritual lokal. Mayoritas masyarakat Ujung menggantungkan harapan-harapannya kepada sanro agar dapat dimediasi dalam mewujudkan apa yang diinginkannya. 
Secara umum keinginan-keinginan masyarakat yang biasanya dimediasi sanro ada dua, yaitu mengharapkan kesejahteraan hidup, dan kelancaran dalam berusaha.

Dampak selanjutnya yang ditimbulkan dapat dilihat pada aspek menurunnya tingkat keyakinan agama masyarakat Ujung. Implikasinya dapat dilihat pada indikator-indikator sebagai berikut: indikator pertama, kurangnya semangat masyarakat menjalankan amalan ibadah dan amalan sosial. Indikator ini menunjukkan bahwa meskipun orang-orang Ujung semuanya muslim, tapi pengamalan dan pengetahuan keislamannya masih kurang. Ada kesan bahwa Islam bagi masyarakat Ujung dipahami sebagai formalitas. Ketika kewajiban beragama telah ditunaikan, maka tanggung jawab keislamannya dianggap telah selesai. Karenanya, tidak menghe-rankan ketika masyarakat Ujung yang berpredikat haji masih tetap mengapresiasi ritual agama lokal yang sarat dengan mistik dan tahayul ini. Demikian pula dalam amalan sosial, budaya solidaritas masyarakat Ujung antara sesama jarang ditemukan dalam kehidupan sosial. Sikap individualistik sangat kental dalam interaksi mereka, terutama dalam menjalankan masing-masing usahanya dalam berdagang.

Akibat kurangnya pendidikan dan pengetahuan agama yang dimiliki masyarakat, maka nilai dan norma-norma agama tidak dijalankan dengan baik, inilah yang menjadi indikator kedua. Kewajiban agama seperti pengamalan ibadah shalat dan zakat, serta norma-norma keagamaan, seperti memperbaiki hubungan silaturahim, tolong-menolong, dan saling membantu tidak mewarnai kehidupan masyarakat tersebut. Bahkan sebaliknya apresiasi mereka terhadap ritus lokal begitu tinggi hingga pengorbanan mereka secara materiil juga banyak. Sikap individualistik juga mewarnai struktur sosial masyarakat Ujung. Karenanya, memahami karakteristik sosial masyarakat Ujung memang unik. Pada satu sisi mereka semua mengaku muslim, namun di sisi lain tidak ditemukannya nilai-nilai dan praktik-praktik keberagamaan tersebut. Selain itu, aturan atau norma sosial juga banyak dilanggar oleh sebagian masyarakat ini. Kebiasaan buruk yang dilakukan seolah menjadi kultur dan karakteristik keseharian masyarakat. Kebiasaan generasi muda mereka minum-minuman keras, berjudi, ditambah aktivitas masyarakat terhadap perilaku mistis menjadi bagian dalam kehidupan masyarakat Ujung. Indikasi tersebut menunjukkan bahwa pengetahuan agama mereka memang tidak sampai pada tingkat aktualisasi dan cenderung tidak diindahkan. 
Kurangnya kesadaran untuk memahami ajaran agama adalah indikator ketiga. Meskipun masyarakat Ujung rajin melakukan kegiatankegiatan seremonial yang terkait dengan perayaan agama atau hari-hari raya besar Islam, tetapi perilaku keagamaannya tetap belum berubah. Memang agak sulit merubah pola pikir masyarakat Ujung yang telah menyatu dengan praktik-praktik ritus lokal. Karenanya, menarik untuk disimak pernyataan yang pernah disampaikan oleh pimpinan pesantren al-Ikhlas Ujung, bahwa "kalau orang-orang tua (masyarakat) Ujung sulit untuk kita luruskan akidahnya, cukup kita membina anak-anak mereka. Ini menunjukkan adanya sikap keras yang dipertahankan masyarakat Ujung, hingga dianggap sulit untuk menerima perubahan. Tidak adanya usaha untuk merubah pola pikir mereka dianggap bahwa orang-orang Ujung memang keras dalam mempertahankan prinsipnya.

Dampak lain yang ditimbulkan adalah adanya kebingungan teologis pada generasi muda masyarakat Ujung. Persepsi yang dikonstruksi dalam imajinasi mereka bahwa praktik-praktik ritus yang selama ini dilakukan oleh orang tua mereka dianggap sebagai bagian perilaku agama. Hal ini berimplikasi lahirnya sikap partisipasi aktif dari generasi muda Ujung dalam melakukan praktik-praktik ritus lokal. Bentuk partisipasi itu dapat dilihat ketika mereka bersama dengan anak-anak yang lain membawa sesajian atau makanan yang akan digunakan dalam upacara ritual di Addewatang. Dalam kognisi mereka praktik ritual yang dilakukan paling tidak mengikuti tradisi yang dilakukan oleh orang tuanya. Adapun, usaha untuk memahami dan mencari tahu kebenaran agama tidak terpikirkan oleh mereka, apalagi lebih banyak dari mereka tidak mengenyam pendidikan. Kendati pun kalau yang sempat menempuh pendidikan, biasanya hanya sampai pada tingkat sekolah dasar (SD). Kini, kultur dan pola pikir seperti itu masih dapat ditemukan dalam masyarakat di Desa Ujung dan kehadiran pesantren al-Ikhlas di Ujung, juga tidak berdampak banyak pada mereka untuk menyekolahkan anak-anaknya di pesantren, sebab kenyataannya hanya sebagian kecil saja yang menyekolahkan anak-anaknya di pesantren ini.

Sikap bervariatif ditampilkan oleh generasi muda Ujung dalam merespons teologis yang dianggap membingungkan mereka. Ada yang bersikap menerima secara totalitas seperti yang dipahami dan praktikkan oleh orang tuanya. Perilaku ritus lokal ini dipercaya sebagai warisan atau peninggalan leluhur mereka. Karenanya, sebagai penghargaan kepada leluhur, mereka 
mentradisikan dan melestarikan kembali kepercayaan ini. Berbeda dengan yang menolak, sikap yang diambil adalah mencoba memberikan pemahaman dan meluruskan kepercayaan yang terlanjur diyakini dan dipraktikkan oleh orang tuanya. Tindakan seperti ini biasanya tidak mendapat respons dari orang tua, justru yang terjadi adalah perdebatan panjang tentang klaim kebenaran masing-masing. Sikap generasi muda Ujung yang seperti ini biasanya mereka yang telah menempuh pendidikan tinggi. Dan mayoritas mereka yang tinggal di luar Desa Ujung atau di daerah perantauan.

\section{Simpulan}

Hegemoni sanro dan relasi kuasanya terhadap ritus lokal ini juga terlihat ketika ritual magisnya dapat mengikat masyarakat Ujung, baik yang berdomisili di Desa Ujung sendiri, maupun mereka yang di perantauan. Orang-orang Ujung rela datang ke Ujung hanya untuk sebuah pemenuhan janji yang pernah diikrarkan sebelumnya. Kuatnya dominasi-hegemoni yang dikonstruksi sanro juga menjadi sesuatu yang menarik, sebab sanro terkesan selalu mendramatisir praktik ritual ini dalam bingkai agama. Implikasinya, masyarakat lebih mengapresiasi dan memberikan kesempatan banyak kepada sanro dalam memandu acara keagamaan dari pada tokoh agama setempat.

Penelitian ini menemukan tiga hal yaitu: Pertama, Praktik dominasihegemoni sanro itu dapat dilihat pada tiga aktivitas keagamaan, yaitu; acara selamatan (tasyakuran). Kedua, acara peringatan keagamaan, dan ketiga pada perayaan hari raya besar Islam. Keberhasilan hegemoni sanro dalam mengaktualisasikan pemikiran masyarakat diwujudkan dengan kuatnya keyakinan masyarakat Ujung terhadap kesempurnaan acara-acara selamatan tersebut baru dianggap sah ketika dilakukan selamatan di Addewatang. Bentuk-bentuk dominasi-hegemoni tersebut dapat dilihat pada proses upacara ritual, bentuk kepercayaan, dan ketergantungan masyarakat Ujung terhadap Putta Sereng, kognisi, dan praktik keagamaan masyarakat Ujung. Kedua, adanya tiga faktor utama terjadinya hegemoni sanro, diantaranya; kuatnya legitimasi (aktor) sanro, dampak yang ditimbulkan akibat akulturasi ritus lokal tersebut dapat diklasifikasi dalam tiga hal utama yaitu; (1) Tingginya loyalitas masyarakat terhadap sosok sanro. Dalam hal ini, sanro dianggap sebagai representasi Putta Sereng. Implikasinya sanro lebih ditempatkan pada posisi yang tinggi dari pada tokoh agama. (2) Menurunnya tingkat keyakinan agama. Indikatornya adalah kurangnya masyarakat menjalankan 
pengamalan ibadah, norma-norma agama tidak diindahkan, dan kurangnya kesadaran untuk memahami ajaran agama. (3) Adanya kebingungan teologis pada generasi Ujung sekarang. Persepsi yang terbangun dalam imajinasi mereka bahwa praktik-praktik ritus yang selama ini dilakukan oleh orang tua mereka dianggap sebagai bagian dari perilaku agama.

\section{Daftar Pustaka}

Abdullah, Irwan. 2002. Simbol, Makna dan Pandangan Hidup Jawa: Analisis Gunungan Pada Upacara Garebeg. Yogyakarta: Balai Kajian Sejarah dan Nilai Tradisional.

Abdullah, Irwan. 1994. Market, Consumption, and Lifestyle Management, makalah yang disampaikan dalam International Seminar on Social and Cultural Dimension of Market Expansion. Batam, 3-5 Oktober.

Abdullah, Irwan. 2006. Konstruksi dan Reproduksi Kebudayaan. Yogyakarta: Pustaka Pelajar.

Beyer, Peter. F. 1991. Privatization and the Publik Influence of Religion in Global Society," dalam Mike Featherstone (ed.), Global Culture: Natiolatism, Globalization and Modernity. London: Sage Publications.

Durkheim, Emile. 2005. Sejarah Agama: The Elementary Form of the Religious Life. Yogyakarta: IRCiSoD.

Foucault, Michel. 1976. Histoire De La Sexualite. Vol 1, La Volonte' de savoir. Paris: Gallimard.

Friedman, Jonathan. 1991. Being in the World: Globalization and Localization, dalam Mike Featherstone (ed.), Global Culture: Nationalism, Globalization and Modernity. London: Sage Publications, hal. 311-328.

Giddens, Antony. 1997. Religion in Sociology. London: Polity Press.

Gramsci, Antonio. 1973. Letter From Prison. New York: International Publisher.

Lathief, Halilintar. 2004. Bissu: Pergulatan dan Peranannya di Masyarakat Bugis. Depok: Desantara.

Rais, Muhammad. 2008. Keberagamaan Masyarakat Ujung-Bone: Sebuah Ritual 
"Addewatang Putta Sereng" di Sulawesi Selatan. dalam buku Agama dan Kearifan Lokal dalam Tantangan Global. Editor Irwan Abdullah, et.,al. Cet.I. Yogyakarta: Sekolah Pascasarjana UGM dan Pustaka Pelajar.

Simon, Roger. 1991. Gramsci's Political Thought: An Introduction. London: Lawrence and Wishart.

Strinati, Dominic. 1995). An Introduction to Theories of Popular Culture. London: Routledge.

Soedarsono, dkk. 1986. Beberapa Aspek Kebudayaan Jawa. Jakarta: DepdikbudJavanologi.

Yauri, Andi Muhammad. 2008. Bissu Gaul: Reinvensi Budaya Kelompok Bissu di Kabupaten Wajo, Sulawesi Selatan, dalam buku Agama dan Kearifan Lokal dalam Tantangan Global. Editor Irwan Abdullah, et.,al. Cet.I. Yogyakarta: Sekolah Pascasarjana UGM dan Pustaka Pelajar.

www. en.wikipedia.org. 2008. Pengantar Hegemoni. 2008. Diakses 25 Oktober 2008. 